\title{
Ekphrasis and metaekphrasis in Julian Barnes's essayistic account of Édouard Manet's paintings of the execution of Emperor Maximilian: a cognitive poetic analysis
}

\author{
T. V. Lunyova \\ Kyiv National Linguistic University, Kyiv, Ukraine \\ Corresponding author. E-mail: lunyovat@gmail.com
}

Paper received 16.11.20; Accepted for publication 27.11.20.

\begin{abstract}
https://doi.org/10.31174/SEND-Ph2020-241VIII72-08
\end{abstract}
\begin{abstract}
The cognitive poetic approach is applied in the article to examine the semantic relationships between ekphrastic and metaekphrastic contexts in Julian Barnes's essayistic account of Édouard Manet's paintings of the execution of Emperor Maximilian. The criterion of the explicit verbal statement that a work of visual art is described in the text was employed to identify ekphrastic contexts. Metaekphrastic contexts were distinguished based on their semantic connection with ekphrastic descriptions and absence of the explicit verbal remark that they render what is depicted in the painting. It has been revealed that ekphrastic and metaekphrastic contexts in Barnes's essay have strong semantic links with each other and ensure semantic multidimensionality of the text thorough their bidirectional semantic connections.
\end{abstract}

Keywords: ekphrasis, metaekphrasis, essay, visual art, cognitive poetics.

Introduction. The paper focuses on the cognitive poetic aspect of the interaction between ekphrastic and metaekphrastic contexts in Julian Barnes's essay about Édouard Manet as they both contribute to generating meanings in the text. The study is grounded in modern interpretation of ekphrasis as "description of a work of art" [13, p. 70] which derives from Leo Spitzer's definition "the poetic description of a pictorial or sculptural work of art" $[9, \mathrm{p}$. 207] and differs from the ancient rhetorical treatment of ekphrasis as "a descriptive speech which brings the thing shown vividly before the eyes" [13, p. 51]. Methodologically the research builds upon the cognitive poetic analysis of ekphrasis $[1 ; 7$, p. 285-290; $8 ; 10 ; 11]$. Thus the study falls within the cognitive poetic endeavour to reveal the mechanisms of meaning construction in various texts.

Literature review. While it has been acknowledged that ekphrasis can be used in texts to generate new meanings $[14 ; 15$, p. 6], the semantic potential of metaekphrasis has not been fully revealed yet. The need to introduce the term metaekphrasis arose from the studies of essays on visual art which besides having clearly exphrastic contexts include contexts that are not a "description of a work of art", however such contexts maintain a strong semantic connection with ekphrastic descriptions per se. For example, Barnes's essay about Édouard Manet contains the following ekphrastic context - a description of the detail in one of Manet's famous paintings: “... I hadn't previously noticed that the naked figure in Le Déjeuner has an almost imperceptible black ribbon in her hair..." [3, p. 79]. The same essay abounds with passages that are not descriptions of artworks, however they are closely semantically related with such descriptions, e.g.: "Those who attack works of art are not, in one sense, wrong. You don't assault something you are indifferent to, or something that doesn't threaten you; iconoclasts rarely smash images out of apathy. Take the man who raised his walking-sick against Manet's Music in the Tuileries Gardens when it formed part of one-man show at the Galerie Martinet in 1863." [ibid., p. 73]. The quoted passage discusses the underpinning motives (You don't assault something you are indifferent to, or something that doesn't threaten you; iconoclasts rarely smash images out of apathy) of extreme reactions to works of art (Those who attack works of art, Take the man who raised his walking- sick against Manet's Music in the Tuileries Gardens). Although it explicitly refers to one of Manet's paintings ( $\mathrm{Mu}$ sic in the Tuileries Gardens), it provides no description of this artwork, i.e. no ekphrasis per se. Since both ekphrastic and non-ekprastic contexts are important for constructing meanings of essays on art, the later contexts should be properly termed to be closely studied.

Whereas the term metaekphrasis can be found in modern scholarship, no unanimous understanding of what metaekphrasis is has been developed yet. Frederick A. de Armas employs the term meta-ekphrasis to account for ekphrasis within another ekphrasis. He states that "an ekphrasis can be contained within another ekphrasis, creating a meta-ekphrasis" [2, p. 22] and illustrates his point with "the drawing of the battle with the Basque within the description of the discovered manuscript of don Quixote in chapter nine of the novel" [ibid.]. Ruth Webb uses the term meta-ekphrasis twice in her book "Ekphrasis, imagination and persuasion in ancient rhetorical theory and practice" [13]: in the title of the chapter "The Poetics of Ekphrasis: Fiction, Illusion and Meta-ekphrasis" (ibid., p. 167) and in the name of the subchapter within this chapter "Descriptions of Works of Art as Meta-ekphrasis" (ibid., p. 185). The researcher discusses the "meta-fictional function" of ekphrasis in this subchapter (ibid., p. 185-186). Even though Armas and Webb do not use the term metaekphrasis in the same way, they both resort to it while discussing some complex semantic phenomena that emerge in the texts dealing with artworks.

From a more practical standpoint, the poet and creative nonfiction writer Janée J. Baugher, reflecting on her experience of writing ekphrastic poetry inspired by the works of art, suggests: "Maybe a better topic for discussion is the limitation of the word ekphrasis. Perhaps meta-ekphrasis is a more suitable term, as ekphrasists tend to transcend the bounds of the object d'art" [4]. As this quote demonstrates, Baugher resorts to the term meta-ekphrasis when a verbal text connected with a work of art goes beyond this artwork, "transcends" it.

A similar reach for "something beyond ekphrasis" can be found in the paper by Renata Gambino and Grazia Pulvirenti [5]. In their analysis of Heinrich von Kleist's text "Feelings about a Seascape by Friedrich" (1810) devoted to 
Caspar David Friedrich's painting "The Monk at the Sea", Gambino and Pulvirenti use the term meta-reflection to reveal the nature of ekphrasis [5, p. 153]. The researchers classify Kleist's text as ekphrastic [ibid., p. 152] while asserting that "the author does not describe or represent the painting, according to the traditional ekphrastic praxis, but the aesthetic, perceptive, emotional and imaginative experience of seeing the picture, i.e. the dynamical affective processes engaged by the reader/ observer in front of the painting, which in Friedrich's intention represents "the act of seeing itself"" [ibid.]. Gambino and Pulvirenti resolve this contradiction (Kleist's text does not describe the painting but is an ekphrasis nonetheless) by arguing that "ekphrasis implies a meta-reflection on the act of seeing an artwork" [ibid., p. 153]. In such a way, through the term meta-reflection, the scholars account for texts that are connected with works of art but are not ekphrastic texts per se.

Following the drive not to extend the term ekphrasis beyond its given definition [6], this study employs the term metaekprasis as it was introduced in our paper with Olga Vorobyova [12] to account for essayistic representation of various facts connected with works of art, discussion of these facts and meditation on various issues (e.g., existential, aesthetic, social, political) prompted by the ekphrastic representation of a work of art. This understanding of metaekphrasis seems to have a strong interpretative potential when used to account for semantics of essays on visual art.

The aim of the study is to reveal the semantic connections between ekphrastic and metaekphrastic contexts in Julian Barnes's essay that considers Édouard Manet's paintings of the execution of Emperor Maximilian.

Material and methods. The material of the research is the second part of Barnes's essay "Manet: In Black and White" [3, p. 73-91] entitled "Less is More" [ibid., p. 8191]. This part of the essay is devoted entirely to Édouard Manet's paintings of the execution of Emperor Maximilian. The criterion of the explicit verbal statement that a work of visual art is rendered or described in the context was applied to identify ekphrastic contexts, e.g.: "In the first version, this NCO is the only character given any sort of defined face, and that is grimly expression-free..." [3, p. 84]. When this statement is absent and a passage does not provide a painting description per se, such contexts were classified as metaekphrastic ones, e.g.: "If in recent years the elephantiasis of exhibitions has eased somewhat - that 2011 Manet show in Paris had a mere 186 items - this is more the result of the economic downturn than of curatorial policy." [3, p. 82]. Overall, 6 ekphrastic contexts and 17 metaekphrastic contexts were singled out. The selected material was scrutinized with the help of conceptual and contextual interpretative analyses.

Results and discussion. Ekphrastic contexts in the essay provide the following information about Manet's three paintings: their colours and hues of (e.g., "gloomy-hued" [3, p. 82], "oceanic colours" [ibid., p. 84], "sunlit, lucid" [ibid.]), the brush-work (e.g., "loose-brushed" [ibid., p. 82]), the people depicted (e.g., "a trio of victims, a huddled firing squad" [ibid., p. 84]), the position the depicted people take ("the soldiers are not lined up" [ibid., p. 85], "their feet are turned out at an angle of 120 degrees or so" [ibid.], "one soldier keeps his heels together" [ibid.]), the glances of the depicted people ("he [the NCO] stares straight out at us" [ibid., p. 86]), the clothes the depicted people wear ("the uniform he had concocted for his firing squad was ambiguous enough to look French as much as Mexican" [ibid., p. 88]), the objects the depicted people have (e.g., "rifle" [ibid., p. 86]), the actions they are performing (e.g. "he is attending to his professional moment, cocking his rifle in anticipation" [ibid., p. 86]), the vividness of the representation of the people in the picture (e.g., "In II his face is smoothly finished and more characteristic; this, you believe, is a particular person" [ibid., p. 86]), the details important for the depiction of people (e.g., "in III it [the right hand] is larger, pinker, more spread: half as big as the left hand" [ibid., p. 88], "the two joined hands of Maximilian and the general on his left" [ibid.]), the background (e.g., "a stretch of open ground" [ibid., p. 85], "beyond are blue mountains and the sky" [ibid.], "a prison yard, with sand underfoot, a high wall behind" [ibid.]), and the symbolic details (e.g., "that saint's halo of a sombrero" [ibid., p. 88]). Besides, there is an ekphrastic account of a detail from Goya's painting "The executions of the third of May 1808" - the artwork which is compared with Manet's artworks, e.g.: "in Goya's Executions the firing squad's stance is a crucial element: the hard ankle, the locked knee, the supporting back leg placed at the correct professional angle" [ibid., p. 85].

In their entirety, ekphrastic contexts ensure vivid and detailed verbal representation of the artworks discussed.

Metaekphrastic contexts in the essay give the information about: peculiarities of the perception of artworks, in particular when there are many of them in one show (e.g., "Two minutes with each exhibit would add up to ten hours..." [ibid., p. 81], "Of course we pick-'n'-mix, the eyeselecting what appeals (or what it already knows)..." [ibid.]) and artworks interpretations (e.g., "It's normally tempting to confuse time sequence in art with progress." [ibid., p. 84]), the art show devoted to Manet's paintings of the execution of Emperor Maximilian (e.g., "It occupied six rooms but was all about one picture or, rather, one subject: Manet's The Execution of Maximilian. " [ibid., p. 82], some current political events (e.g., "Nowadays, when a debtor nation is obliged to defer its financial obligations, the powers-that-be send in teams from the IMF, the European Central Bank, the European Commission, and so on." [ibid., p. 83]), the historic event behind Manet's paintings the political crisis which lead to the execution of Emperor Maximilian (e.g., "They [the French] installed Austrian archduke Ferdinand Maximilian as Emperor in 1864, guerrilla war broke out the following year, the occupation collapsed, the French withdrew, Maximilian declined to abandon his puppet throne, and the returning Mexican government executed him with two of his generals..." [ibid., p. 83]), the reaction of contemporaries to that historic event (e.g., "The event made international news." [ibid.]), what is known and what is unknown about Manet's creative process as he painted his three paintings devoted to the execution of Maximilian (e.g., "The news also made Manet plunge into art..." [ibid.], "We do not know why he abandoned the second version of the painting..." [ibid., p. 84]), the critical reaction to Manet's artwork (e.g., "One contemporary critic complained that Manet's work manifested "a sort of pantheism which places no higher value on a head than a slipper." " [ibid., p. 88]), Manet's assessment of his own work (e.g., “... when the lithograph of the Execution was banned in 1869, Manet described it in press 
statement as "une oeuvre absolument artistique.", [ibid.]), the reception of Manet's artworks (e.g., “... the final paint-

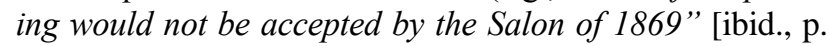
90]), the relationships between political events and art (e.g., "Either the work is artistically "pure" and just happens to have been taken from recent political events; or it isn't." [ibid.]), and the phenomenon of censorship (e.g., "They [censorship bodies] are notoriously quixotic, developing their own eccentricities and exaggeratedfears. "[ibid.,p.91]).

In their wholeness the metaekphrastic passages situate the discussion of Manet's artworks in the particular historic context and take this discussion beyond deliberation on Manet's paintings to contemplations on art and its perception as well as art and political events and social phenomena. Since metaekphrastic contexts are more numerous than ekphrastic ones (17 over 6) and longer, the essay transcends the consideration of some specific works of visual art.

The ekphrastic contexts constitute the semantic core of the essay - they represent three Manet's paintings as well as one Goya's painting. As such ekphrastic contexts semantically prompt metaekphrastic contexts. The metaekphrastic contexts are connected with the ekphrastic contexts via two types of semantic relationships: on the one hand, the metaekphrastic passages semantically support the ekphrastic passages through providing the information necessary to understand the exphrastic descriptions of the artworks (e.g, the quoted above account of Emperor Maximilian's real story is necessary to comprehend what is going on in Manet's paintings), on the other hand, metaekphrastic contexts take the discussion in the essay beyond particular paintings (e.g., towards consideration of peculiarities of the perception of artworks or role of censorship). Metaphorically speaking, metaekphrastic contexts both nourish the ekphrastic contexts and feed on the ekphrastic contexts. These semantic connections are schematically represented in Figure 1.

As Figure 1 demonstrates, metaekphrastic contexts form three semantic clusters in Barnes's essay. Each cluster is semantically sustained by one dominant theme: i) art exhibitions, ii) political events and art, and iii) art and censorship. In each semantic cluster there are metaekphrastic contexts that ensure the understanding of the ekphrastic descriptions of the artworks (marked with light grey in Figure 1) as well as metaekphrastic contexts that transcend the discussion of particular artworks and deliberate more general issues (marked with dark grey in Figure 1). While the ekphrastic contexts are always more specific being connected with particular artworks, the metaekphrastic contexts are of two semantic types: more specific and more general. Thus the essay is semantically multidimensional and its original semantic content is created via fluctuations from more general to more specific and from more specific to more general.

Such semantic structure of the essay allows Barnes to provide rich and substantial information about Manet's paintings of the execution of Emperor Maximilian as well as consider more general issues connected with visual art. The readers of the essay are encouraged both to learn more about Manet's artworks and to contemplate the challenges of perceiving a great number of works of art within a limited period of time, the principles of artistic response to political events and the phenomenon of censorship. In this way the readers are enabled to appreciate the complexities of the particular artworks and to pay attention to the connections between art and real life. Thus being an essay on visual art, Barnes's text is by no means an essay for artwork description sake.

Conclusion. The strong semantic interdependence of ekphrastic and metaekphrastic contexts on each other in Julian Barnes's essayistic account of Édouard Manet's paintings of the execution of Emperor Maximilian ensure its multidimensional semantic structure and potential relevance to those interested in Manet's art as well as concerned with more general issues related to visual art. Further research will provide deeper insights into the semantic relationships between ekphrastic and metaekphrastic contexts in essays on visual art.

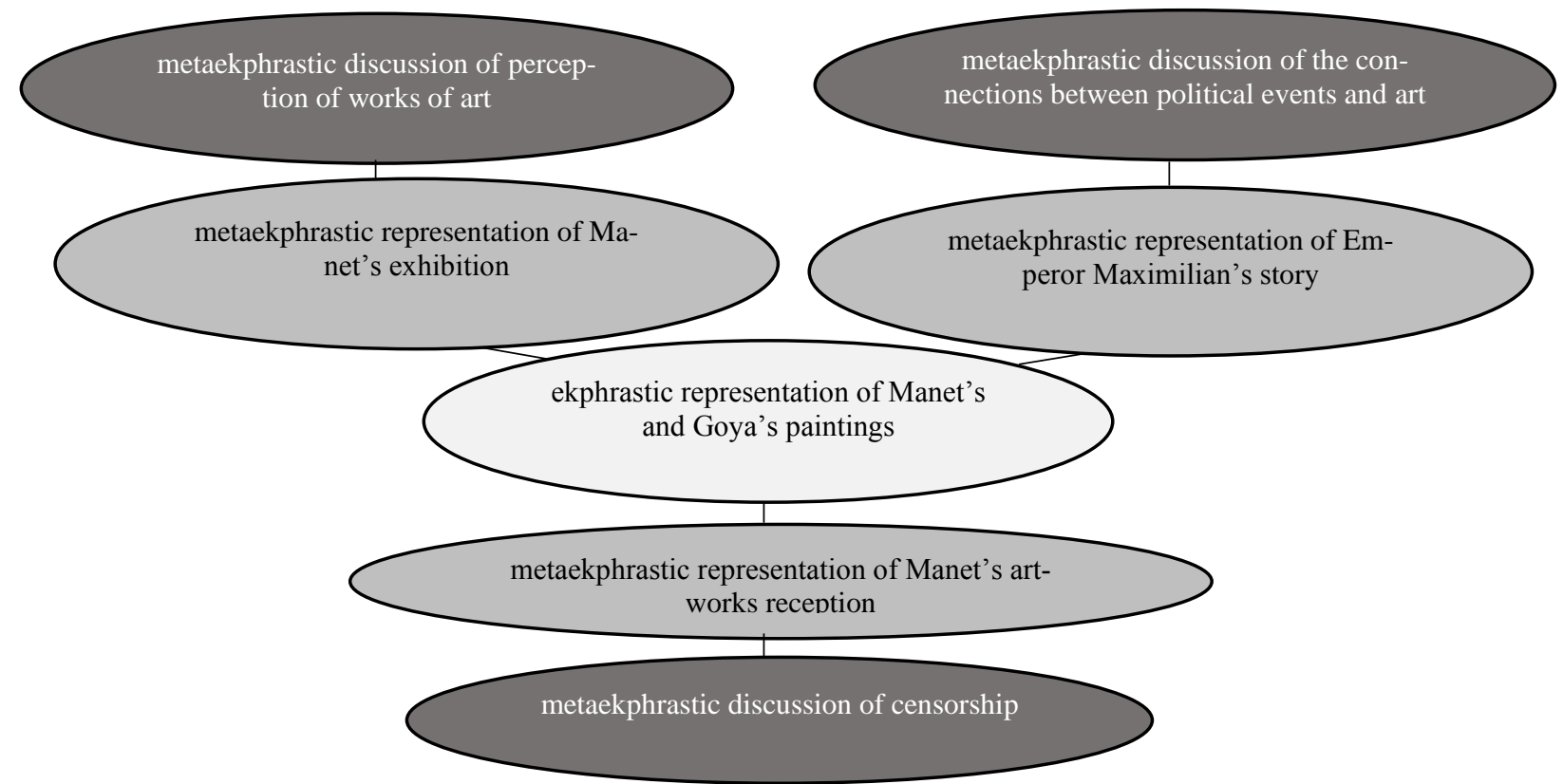

Figure 1. Semantic connections between ekphrastic and metaekphrastic contexts in Julian Barnes's essayistic account of Édouard Manet's paintings of the execution of Emperor Maximilian 


\section{REFERENCES}

1. Andreeva K.A., Beloborod'ko, E.K. New approach to very traditional notion "ekphrasis": in the dialogue of linguistics and art // Universum: Philology and arts studies. 2016. No 11 (33) // Андреева К.А., Белобородько Е.К. Новые подходы к вполне традиционному понятию “экфразис": в диалоге лингвистики и искусства // Universum: Филология и искусствоведение. 2016. № 11 (33). Available at: https://cyberleninka.ru/article/n/novye-podhody-k-vpolnetraditsionnomu-ponyatiyu-ekfrazis-v-dialoge-lingvistiki-iiskusstva

2. Armas de F. A. Simple Magic: Ekphrasis from Antiquity to the Age of Cervantes // Ekphrasis in the Age of Cervantes / Ed. by F. A. De Armas. Lewisburg, PA: Bucknell University Press, 2005. p. 13-31.

3. Barnes J. Keeping an Eye Open: Essays on Art. New York: Vintage International, Vintage Books, 2015/2017. 278 p.

4. Baugher J.J. Art to Art: Ekphrastic Poetry // Boulevard. Available at: https://boulevardmagazine.org/jjbaugher

5. Gambino R., Pulvirenti G. The Paradox of Romantic Ekphrasis. Metacritic Discourse, Perception and Imagination in Art Description // Metacritic Journal for Comparative Studies and Theory. 2017. No 3 (1). p. 151-179.

6. Generalyuk L. Ekphrasis and hypotyposis: Problems of differentiation // Word and Time. 2013. No 11. p. 50-61 // Генералюк Л. Екфразис і гіпотипозис: проблеми диференціації // Слово і час. 2013. №11. С. 50-61.

7. Izotova N.P. Ludic stylistics of contemporary English fictional narrative from a linguistic perspective: A study of J.M. Coetzee's novels: Thesis for the Doctor's degree in Philology. Speciality 10.02.04 - Germanic languages. Kyiv: Kyiv National Linguistic University, 2018. 458 р. // Ізотова Н.П. Ігрова стилістика сучасного англомовного художнього наративу в лінгвістичному висвітленні (на матеріалі романів Дж.М. Кутзее): Дисертація на здобуття наукового ступеня доктоpa філологічних наук. Спеціальність 10.02.04 - германські мови. Київ: Київський національний лінгвістичний університет, 2018. $458 \mathrm{c}$.

8. Panagiotidou M-E. Ekphrasis, cognition, and iconicity: An analysis of W. D. Snodgrass's "Van Gogh: 'The starry night"” // Dimensions of iconicity / Ed. by A. Zirker, M. Bauer, O.
Fischer, C. Ljungberg. Amsterdam - Philadelphia: John Benjamins, 2017. p. 135-150.

9. Spitzer L. The "Ode on a Grecian Urn," or Content vs. Metagrammar // Comparative Literature. 1955. Vol. 7. No 3, p. 203225.

10. Verdonk, P. Painting, poetry, parallelism: Ekphrasis, stylistics and cognitive poetics // Language and Literature. 2005. No 14 (3), p. 231-244.

11. Vorobyova O. Virtual narrative in Virginia Woolf's "A simple melody": Cognitive and semiotic implications // Language literature - the arts: A cognitive-semiotic interface. Ed. by E. Chrzanowska-Kluczewska, O. Vorobyova. Frankfurt am Main: Peter Lang, 2017. p. 95-112. (Text - Meaning - Context: Cracow Studies in English Language, Literature and Culture / [Chrzanowska-Kluczewska, E. \& Witalisz, W. (eds.)]. Vol. 14)

12. Vorobyova O., Lunyova T. Verbal and non-verbal facets of metaekphrastic writing: a cognitive study of Jonh Berger's essays on visual art // Lege artis. 2020. In print.

13. Webb R. Ekphrasis, imagination and persuasion in ancient rhetorical theory and practice. London and New York: Routledge, 2009/2016. 238 p.

14. Yatsenko E.V. "Love painting, poets...”. Ekphrasis as an artistic worldview model // Issues in philosophy. 2011 // Яценко Е.В. “Любите живопись, поэты...”. Экфрасис как художественно-мировоззренческая модель // Вопросы философии. 2011. Available at: http://vphil.ru/index.php?option=com_content\&task=view\&id= 427

15. Zagorodneva K.V. The genre of essay about art in English literature of the second half of the nineteenth century: Synopsis of the thesis for the Candidate's degree in Philology. Speciality 10.01.03. - Literature of foreign countires (English literature). Ekaterinburg: Ural State Univeristy named after A.M. Gorky, 2010. 21 р. // Загороднева К.В. Жанр эссе об искусстве в английской литературе второй половины XIX века: автореферат диссертации на соискание ученой степени кандидата филологических наук. Специальность 10.01.03. - литература народов стран зарубежья (английская литература). Екатеринбург: ГОУ ВПО "Уральский государственный университет им. А.М. Горького", 2010. 21 с. 